\title{
Voice matters: Students' struggle to find voice
}

Authors:
Toni Gennrich 1 (1)
Laura Dison ${ }^{1}$ (
Affiliations:
'School of Education,
University of the
Witwatersrand, South Africa
Corresponding author:
Toni Gennrich,
toni.gennrich@gmail.com
Dates:
Received: 19 Aug. 2017
Accepted: 27 June 2018
Published: 15 Nov. 2018
How to cite this article:
Gennrich, T. \& Dison, L.,
2018, 'Voice matters:
Students' struggle to find
voice', Reading \& Writing
9(1), a173. https://doi.org/
10.4102/rw.v9i1.173
Copyright:
○ 2018. The Authors.
Licensee: AOSIS. This work
is licensed under the
Creative Commons
Attribution License.

Attribution License.

\section{Read online:}

Often, at universities, it is assumed that students will automatically find their 'voice' after a period of exposure to the academic field. What is not understood fully are the struggles that students with different levels of preparedness have in finding and asserting their academic voice, particularly in the academic writing genres necessary for success. There is a clear link between students' ability to exercise voice and their achievement levels. The data focussed on in this article were drawn from a large assessment study that aimed at reaching an in-depth understanding of why first-year Bachelor of Education (BEd) students experience difficulty with their assessment tasks. Focus groups were held with 18 firstyear volunteer BEd students. In particular, we focussed on the unique insights emerging from the data about the challenges students face in finding their voice. We identified how a lack of understanding of the purpose of assessment contributes to these struggles. Other factors that contributed to this are difficulties with the genre of academic writing, challenges with vocabulary and positioning oneself in relation to the theory. Many students appeared not to feel a sense of agency or confidence in their capabilities and have poor self-efficacy beliefs. These aspects were underpinned by the requirements of assessment and necessitate that lecturers develop pedagogical strategies to make the acquisition of voice more explicit.

\section{Introduction}

To write academically, ensuring the clarity of one's argument and the presence of one's voice, is more cognitively and linguistically demanding than is often appreciated by those who work with first-year students. Students struggle to find the balance between drawing on theory or previous knowledge and taking up their own positions while building on that knowledge, particularly when they are writing in a language that may be a third or fourth language. Often, students arrive at university having been poorly prepared (Gee 2008) by a school system and assessment practices that do not foreground academic writing. This is because they did not receive adequate exposure to writing academic essays and, as a result, are unaware of the demands of the genre (Bangeni \& Kapp 2017). The view of knowledge that is established in many of the schools our students come from, is that it is fixed and there is a reliance on memorisation and regurgitation. Students also struggle to understand the disciplinary norms that govern the language conventions required in their different subjects and this affects their ability to write successfully in different academic domains.

Although some lecturers communicate to students the importance of voice in academic writing, they generally do not provide opportunities for their students to enact this as a central aspect in their lecture rooms and may assume that students are learning how to find their voice in other academic spaces at the university. Given the poor performance of the 2010 cohort of Bachelor of Education (BEd) students at the Wits School of Education (WSoE), the rationale of this study was to investigate the assessment practices and students' experiences of academic writing at this particular academic institution, in an attempt to better understand the challenges that tertiary students in South Africa face in finding their voice (Dixon, Reed \& Reid 2013; Shalem et al. 2013a; Shalem, Dison \& Reed 2013b; Shalem \& Rusznyak 2013).

\section{Voice, reading and assessment}

Cliff (2015), in reflecting on the findings of the National Benchmark Test, contends that many firstyear students struggle with reading, comprehending, making inferences and engaging critically with ideas and concepts. We recognise the centrality of reading, as it allows students to envisage the possibilities that exist for developing voice if they are able to make the connection between what they read and their academic writing. Using academic texts as a model across disciplines and academic literacy courses enables the acquisition of the vocabulary, genre, style and register necessary to write academically in resourceful ways. 
Furthermore, we recognise the critical role that writing academic essays plays in promoting learning and thinking and argue that it should not only be used as a tool for measuring achievement. This perspective supports Carless' (2015) argument for a 'learning orientated assessment framework' in higher education (p. 27), which distinguishes between assessment for learning and assessment of learning. In response to arguments that assessment often overshadows teaching and learning in 'ways that are not conducive to a good university education', Carless (2015:10) proposes strategies for designing well-formulated assessment tasks and effective feedback practices that stimulate meaningful learning. He suggests that students have the potential to become 'assessment literate' as they engage with assessment criteria and feedback as a means of understanding the 'tacit nature of quality' (p. 138).

\section{Voice and academic writing}

Although there is no universal way to define academic writing, it 'involves forms of reasoning, analysis, modes of investigation and self-reflection which enable the critical examination of established truths, taken-for-granted assumptions and knowledge handed down by tradition' (Slonimsky \& Shalem 2006:38). As mentioned earlier, negotiating new writing discourses is challenging for students and calls for an in-depth understanding of perspectives on student voice.

Voice is a contested concept (Oostendorp 2016; Pearce \& Wood 2016; Sperling et al. 2011) and has been used in a number of ways in various disciplines. The use of the metaphor of 'voice' for enabling agency and asserting identity is useful (Sperling et al. 2011) and it is this viewpoint that underlies our discussion. Bakhtin (1981) distinguishes between the individual voice and the social voice, emphasising that individual voice develops in relation to other voices. As our aim is to discuss how first-year students struggle to find their individual voice within the social demands of the disciplines they are studying, this relationship is important. The challenge students encounter is to position themselves within fields where there are powerful 'ideological points of view, approaches, directions and values' (Bakhtin 1981:346). The issue of voice in academic institutions needs to be viewed against the fact that there are fields that reproduce hegemonic voices, while there are also those that empower students to assert their 'linguistic and social resources' (Pearce \& Wood 2016:4) to contest the field and transform it. This is particularly relevant in our context, an urban university in Johannesburg, South Africa, where students are calling for the decolonisation of the curricula and transformative pedagogies. Blommaert (2008) argues that it is the extent to which one can make oneself understood on one's own terms that enable voice. Often, the resources and capacity one has (especially linguistically and in terms of academic literacy) make it difficult for students to do this successfully. Many students arrive at university, not having been exposed sufficiently to the linguistic, stylistic and generic resources (such as the features of an academic essay) which are required in their academic field. Blommaert (2008) is critical of institutions which emphasise uniformity and do not take into account divergent ways of being literate or different 'ways with words' (Heath 1983). Despite this, there is a strong emphasis on uniformity in many academic domains, which causes students' voices to be silenced because their repertoires of literacy practices do not match the normative expectations of the institution (Blommaert 2008). This is evident when individuals need to write in a 'borrowed' genre (Blommaert 2008:50) such as the academic essay, a genre with which they are not comfortable. Those who do not have access to a large collection of texts that may serve as models, try to approximate the genre but this is generally not fully realised. In the process of 'trying on' and 'parroting' academic discourse (Angélil-Carter 2000; Crème \& Lea 1997), students do not integrate the material they use into their own thinking. They also do not recognise how academic discourse is situated in different academic contexts differently and how it is about more than reading and writing, but includes values, attitudes and social relationships (Gee 1990).

In unpacking the role of voice in academic writing, it is important to consider the academic reading and writing practices that different disciplines require from their students. Boughey and McKenna (2016) challenge educators to reflect critically on what has been considered the 'common-sense assumptions' (p. 7) or what Cadman (2003:1) calls 'divine discourse' that dominate in their disciplines. Educators need to recognise that the literacy practices required in their disciplines are not neutral; they are powerful and often silence voices and deny epistemological access. Not making these practices clear, denies access to the knowledge systems located in different disciplines within the university.

\section{Voice and power}

In helping students to recognise what knowledge is valued in different fields, we are conscious of the issues of power that inhibit students' voices. Students find themselves in various academic fields, where what is valued as capital is often different from what they acquired in other fields (Bourdieu 1990, 2004), such as the subjects they studied for Grade 12. The academic field recognises forms of cultural capital which are tied up with the knowledge of long-established norms and values. This knowledge is inextricably linked to power, identity and capital (Luke 2008). Lecturers, tutors and examiners hold the power in academic fields and it is they who decide which voices are acceptable and which are not (Pearce \& Wood 2016). Sperling et al. (2011) emphasise that voice should be considered in its ideological sense, recognising that equity and access are not the same for students in the contexts in which they learn to read and write. It is this that leaves first-year students confused and disempowered as they try to understand how to assert themselves in new academic genres that are different from the genres of writing they are more comfortable with. As many students face this struggle, they 'are alienated from the subject and the process of 
study itself' (Mann 2001: 7). This is complicated because those who teach in academic disciplines at university level are not always overtly aware of the explicit writing conventions required in their field, and thus find it difficult to explain to students what exactly is required. Also, these conventions, though similar across the curriculum, are more likely to be discipline specific.

Language, voice and power are linked and language is essential in reinforcing and reproducing the norms of different discourses and the associated values in fields which enable voice. Symbolic power is given to writers and speakers who are viewed as being 'legitimate' or 'authorised to speak' in particular fields (Bourdieu 1991:41). Because many students in the context in which we teach and in which this study was conducted, speak many languages, with English being one of them, it is important to consider how the use of language can limit students' voices. Students are asked to function successfully in environments where they are measured by their achievement in resources that they do or do not have - their embodied capital (Bourdieu 1986).

Many students in the South African context do not have sufficient linguistic resources to express themselves in writing in ways that reflect their unique individuality (Johnstone 2000 in Sperling et al. 2011). This is often true of their first language, which they would not have used as language of learning and teaching beyond Grade 3. It is even more difficult to find the vocabulary, syntax and punctuation to do this successfully in a language that one is not comfortable in. Although many of our students speak a number of languages which provide them with cultural capital (Bourdieu 1986), these languages are not sufficient to provide the symbolic capital necessary to achieve in an environment where English is the powerful language, that is, the language of learning and teaching and assessment.

\section{Voice and self-efficacy}

Self-efficacy is defined as 'students' beliefs in their abilities to complete their studies' (Ashwin et al. 2015:33). Dweck (2016) outlines two broad ways in which students understand their abilities. They either see ability as fixed, which cannot be changed as a result of learning, or they have an incremental view of their abilities that can be changed through learning and teaching. Our focus is on how students negotiate the content and processes of their disciplines and develop their voices in response to the challenges they face. Their motivation and belief in their ability to succeed is relationally fluid and is produced through social interaction. We support Ritchie's views (2016) that qualities like self-efficacy need to be developed in different learning contexts and require learning and feedback experiences that develop their capacity for selfjudgement. Although students are motivated to succeed, their voices may not emerge confidently in certain learning contexts. Motivation is not a predetermined quality and will not influence learning positively if students are not sufficiently engaged in teaching and learning activities.

\section{Research methods and data analysis}

The participants in this study comprised of 18 first-year students, who were divided into three racially and gendermixed focus groups. The focus group interviews were held in October 2010. No attempt was made to obtain a racially or gendered representative sample and the only criterion for inclusion in the study was the students' performance on a compulsory first-year course Education Theory, which forms part of the curriculum at the WSoE. A total of 490 students were registered for this course in 2010. This course was selected as all students have to complete it, regardless of their specialisation. After the ethics approval was granted by the WSoE, all the students were invited to participate; however, only 18 students volunteered to participate in the focus groups. It was explained to them that they could withdraw from the study at any point and confidentiality and anonymity were guaranteed as far as possible. The participants signed informed consent forms, indicating their understanding of the purpose of the study and their right to withdraw from it. After signing their consent forms, the participants were divided into three groups, based on their achievement in the course Education Theory. Group A consisted of low achievers, group B consisted of average achievers and group C consisted of high achievers it. An overview of the participants in the three focus groups is presented in Table 1.

The focus group interviews, which were recorded and transcribed, consisted of 15 questions covering students' understanding, experiences and explanations of the following: the aim of assessment in general at first-year level and its relation to learning, the differences between school and university assessment, the importance of assessment criteria, the tasks required across different courses, the perception of fairness in marking, the quality of feedback provided and suggested ways for improving the first-year assessment plan.

Data analysis included close reading and thematic analysis of the transcriptions, looking particularly for references to voice, the purpose of assessment, language issues, voice and power. As a result of our inductive analysis of the data, three themes emerged: participants' understanding of the purpose of assessment, their awareness of the limits of their vocabulary and their difficulties with positioning themselves in relation to the theory. In the next section, we focus on these themes and how they pertain to students' struggles with voice in written assessments.

\section{Ethical considerations}

Permission to conduct the study was obtained from Wits School of Education Ethics Committee (approval no. 2007ECE09).

TABLE 1: Overview of focus groups.

\begin{tabular}{llcc}
\hline Name of group & Description & Number of students & \% obtained \\
\hline Group A & Low achievers & 7 & $40-50$ \\
Group B & Average achievers & 6 & $50-60$ \\
Group C & High achievers & 5 & $70-80$ \\
\hline
\end{tabular}


Y. Shalem who was the project leader, played a significant role in directing research on assessment practices at the WSoE.

\section{Findings and discussion}

Our examination of the data shows that first year students experience a broad range of difficulties in their academic studies, and more particularly, that finding their voice in academic writing is challenging.

\section{The purpose of assessment}

It is difficult for students to find voice in writing their assessment tasks when their view of the purpose of assessment is limited. The low-achieving students in the assessment study (Group A) perceive the purpose of assessment to be primarily for marks and as a measure of whether they should pass or fail a particular course:

'I think for me, it's like, the purpose is ... proceeding to next year. I don't see a deep purpose' (Group A, S4, Male).

Another student from the same group concurs:

'Yes, just looking for passing ...' (Group A, S3, Male).

Another suggests the purpose of their assessment is:

'... to test our knowledge [and to see] how we cope with that course' (Group A, S1, Male).

For students preoccupied with assessments that value certification and obtaining high marks rather than engaging in learning processes that stimulate higher order thinking, assessment is experienced as summative rather than formative and the focus shifts from 'writing to learn' to 'writing to achieve' marks. A student from Group B discusses how his perception of assessment is that it is summative:

'We are focusing more on passing the assignment, not actually why we are passing ... Because we don't get even a chance to maybe try and ... you need to test our understanding before, before we get an assignment, we're not doing anything, just go to a lecture, take notes, discuss in tutorials, they won't give us a chance to maybe see and test if maybe you are understanding, you're in the right direction, you just get one assignment, and if you fail, you fail.' (Group A, S3, Male)

The 'why we are passing' becomes obscured. This student recognises that assessment should do more than just focus on the marks achieved, that there needs to be a grasp of why he is either understanding or not understanding in order to learn from the task, but because of the timing of some of the assessments (at the end of the teaching block with no formative structure leading towards them), he views assessment as summative. Because formative writing is not supported in the curriculum, he suggests that he is more focussed on marks than the learning process involved in completing the assignment.

Related to this notion of knowledge being fixed, rather than something to be grappled with and built upon, is the students' frustration in not understanding the reasons they get something wrong, and thus settling for mediocrity:

'I will give them their 50 because they don't want to give me more. But I'll give them $50 \%$... that's it' (Group A, S3, Female).

This student displays defiance in the face of not being able to achieve well, no matter how much work she puts in. She claims to be satisfied with $50 \%$.

Another student also articulates this exasperation:

'You can try your best and do what they tell you but then still when you come back you see our marks just scraping fail or scraping pass. Why don't you get 90 or something, when you've done whatever they said?' (Group B, S2, Female)

These students' limited self-efficacy leads to frustration and withdrawal from any attempts to develop. The frustration lies in not having the strategies to achieve well, despite effort on their part. The latter student is exasperated at not understanding what is expected, thinking that she has complied with the demands set by the anonymous, powerful 'they' who are arbiters of whether she has achieved well or not and who are seemingly never satisfied. What she expresses here, borders on thinking that academic ability is predetermined and that she has no hope of attaining it. The feedback these students receive often emphasises how far they still have to go, rather than focussing on development and growth, thus reinforcing their low self-efficacy. This contrasts with Ritchie's (2016) depiction of students with high self-efficacy as being able to achieve mastery because: 'they understand what they have done, the sense of their learning self and of their capabilities which are affirmed and transformed' (p. 4).

\section{Academic genre and vocabulary}

Another challenge the students face is working with an unfamiliar genre. They realise that this is something new to them and recognise that the writing required is quite different from what they have written before, but they are unable to recognise how to bridge the gap. Again, they focus on an external, fixed genre that should be attainable, not recognising how to use the genre for their purposes and to express themselves within its conventions. As one student suggests the purpose of assessment should be:

'Just to get us used to the type of writing university requires. And compare it to our usual way that we used to write in school which is completely different from university.' (Group B, S1, Female)

She understands that there is a division between her previous experience of writing and the current demands made on her; however, there is confusion about the specifics of what this entails.

Another prohibiting factor in finding voice in assessment is not being able to understand the vocabulary used in the assignment questions and/or not understanding the terminology used in the assessment criteria. Students also often do not have the vocabulary to express themselves 
adequately. Students struggle with the notion that academic writing requires the use of complicated vocabulary. Many do not have the linguistic capital (Bourdieu 1991) to cope with both the academic reading and writing expected. In a multilingual environment, such as the one we work in, the first issue students have is that they do not possess the vocabulary required to write in a language that is not their home language. In trying to unpack why he did not do well in a particular assignment on identity, this student remarks:

'I don't know how they work, but they want those bigger words that we don't have.' (Group A, S3, Male).

His view is that complicated language equates with academic writing and recognises that he does not have the linguistic capital to meet these demands.

However, what is evident from the data is that the language struggles that students face are more complicated. This supports Cliff's (2015) argument that the language barrier first-year students struggle with is threefold and comprises vocabulary, academic jargon and finally the genre vocabulary, that is, the vocabulary necessary to write about academic writing.

Working from a narrow interpretation of what constitutes knowledge, the Group A students struggle to succeed in academic writing. Tasks that do not require them to engage with difficult terminology are viewed as easier:

'So it's much easier for us to just pass other tasks than when you write the essays that you must read [for]. The terminologies of some theorists that have that "constructive" and other big words.' (Group A, S3, Male)

Dealing with academic language is complicated by the fact that some of the words mean different things across different subjects; in other words, there is jargon that is specific to each academic domain:

'Like when we are describing those developmental stages of Piaget, and you will have ... "equilibrations"... when you compare it to Physics or Science, "equilibration" means something else' (Group A, S3, Male).

Students who do not achieve well, blame the 'language barrier' for their poor achievement and suspect that this is the reason they are being marked down. However, while making this claim, there is a suggestion that they are not entirely sure of this fact. This uncertainty reflects the lack of understanding they have as to what exactly the requirements of the genre are and with this comes exasperation at not getting explicit instructions and feedback:

'They had to specify at the end if your language is poor. They must say "your language is poor" so that you maybe improve in the future. But they don't specify. You just get maybe $48 \%$ but they don't tell us.' (Group A, S2, Male)

Students recognise that there is a need to write academically but are unable to articulate exactly what this means:

'And when you're expressing your views, you have to express in a very academic way ... very, very academically' (Group B, S1, Female).
This student does not know how to bridge the gap between what she thinks is expected and how to produce it and this is reflected in the lack of meta-discourse to describe what the writing requires.

In one of their subjects, students were asked to complete an assignment which required them to relate their personal literacy practices to the notion of identity. In reflecting on their achievement on this assignment, they indicate how perplexing it was to understand the reasons why they did badly. The assignment asked them to write personally and to relate this to the theory on the literacy and they struggled with the balance required. Their interpretation of where they went wrong reveals that they have not grasped how to achieve this balance. One student argues:

'I was saying my views, but they marked it wrong.' (Group A, S2, Male)

He is convinced he was marked down for his opinions because:

'I didn't see any correction in my assignment.' (Group A, S2, Male)

This student is operating from the assumption that his work would have shown correction of language errors, had faulty language been the reason he had failed. Another student suggests that language use is the problem because:

'I think they want something like those specific words to put how you reflect yourself ... Words you must come up with that will reflect on how you are.' (Group A, S3, Male)

There is an attempt to understand what went wrong and a recognition that drawing on the discourse of the field is important but the focus is on vocabulary rather than engagement with the theory. Because at some schools, the focus tends to be on form and not substance, first-year students cannot understand that they are assessed on intangible connections in the content and they look for the specific corrections of form.

The high achievers recognise the gap between the language used for writing at school and that required by the university. They have the necessary meta-awareness of the vocabulary requirements and this comes as they grapple with the academic readings:

'And one reading is like ... it takes forever to read. Because I mean, coming out of matric and then come to university, the language itself is a huge jump' (Group C, S4, Female).

This group of students is not only able to recognise the discontinuity (Shalem et al. 2013) between what assessment entailed at school and what is expected at university, but also has the language to articulate it:

'At high school it's more about do you remember the facts ... whereas here is so much better ... there's a shift from working out the answer and actually knowing why the answer is that way.' (Group C, S2, Female) 
This student is able to verbalise how the goal of assessment is different at the university and can make a judgement about what is required to meet these goals.

The achieving students recognise the difference between deep and surface engagement in their writing. The struggling students, on the other hand, cannot work out for themselves why they are not doing well.

\section{Academic genre and positioning oneself in relation to theory}

The third misunderstanding about the genre of academic writing is how to insert one's voice into writing while drawing on theory:

'You need a lot more facts; you need a lot more academic readings that you need to do. So, it's not based on your creativity and your thinking, it's based on your understanding of a person's facts and their research and stuff.' (Group B, S1, Female)

This student recognises that the academic essay requires one to draw on theory but misunderstands the genre, not identifying the importance of her own intellectual engagement, seeing her creativity and thinking as being constrained. She has not grasped how to insert her own thinking into the knowledge she is drawing on and how to express this in creative ways.

Another student describes how she experiences being constrained by the need to write 'academically':

'You can't really express yourself ... And when you're expressing your views, you have to express it in a very academic way. It's not very personal. It's more academic than creative ... Because you've got to just express what you see, everything, you can't exactly give in your own words, you've got to do it very, very academically.' (Group B, S1, Female)

The vagueness with which this student expresses the requirements for academic writing indicates the limited understanding she has of what is required. The only characteristics she identifies as being necessary for an academic essay are that the writing is not personal and should not be written in one's own words. What is meant by 'academic' is unclear to her. Her focus is on expression rather than conceptual understanding.

This contrasts with the recognition by a well-achieving student that one difference between school and university writing lies in the use of theory:

'I think for school we weren't taught in theories, here it's if you understand something.' (Group C, S1, Female).

This student identifies a specific discontinuity between what was expected at school and what is expected at university, namely, the need to explain why an answer is the way it is; the theoretical underpinnings to the knowledge. It is being able to recognise the differences and having the language to articulate them which helps this student to overcome the challenges of inserting one's voice into academic writing.
Part of the difficulty of integrating one's voice with that of the theorists one draws on in writing is the dilemma of how much detail to include and how much elaboration is required:

'It's not like at high school, they might ask you a question: how are tables made? In high school you can just say, wood from trees. But here, you have to elaborate, one question they expect you to write some sort of a small paragraph, it's elaborate more on what you say. That's what I've seen. That's why I didn't perform well in my June exams.' (Group B, S2, Female)

As discussed, many students come from an environment where the accurate recollection of facts is important, and so the shift to having to analyse, justify and critique is challenging. The requirement to elaborate is not fully understood and is seen as writing quantity - 'some sort of a small paragraph' - rather than any understanding of what is required in the elaboration to make it acceptable. It is not only the weaker students who struggle with this. A high achieving student also comments on the challenges faced by having to elaborate:

'I think to myself, OK, I already had five pages, which was the limit, and so if I did actually elaborate on this, then where was I supposed to fit it in? So sometimes it's more of what should I mention and what shouldn't I mention?' (Group C, S3, Female)

However, this student seems to be more aware of what 'elaboration' entails, that it requires choices and selections to be made about what is important or not. As she grapples with the requirements of the discipline and the quantity of content, it is difficult to decide what to include or not.

A further difficulty for all of the students in dealing with the requirement of 'elaboration' is a lack of understanding of how to insert their voice into their writing or to position themselves in relation to theorists. The accusation of plagiarism hangs over their heads and it appears to be something that they do not understand how to overcome:

'Sometimes you don't even see that you're plagiarising. Because you don't know whether ... you have to use the theorist's key words, explain them according to what he said, not forgetting that you have to put your input, so sometimes ... I failed the two assignments in first semester because of this, I couldn't ... the first assignment they said you must write in your own words how you understood. I wrote that, I got 40 ... They told me that you must write mixing with the books, don't use your own knowledge, use the books, like the theorists. I wrote about the theorists, I failed, then I got 45. I went there again, they said, don't talk too much of the theorists, mix with your own ... (laughter). I even cried because I wasn't sure how to balance. Because if you try to balance then you plagiarise.' (Group B, S2 Female)

This student's exasperation at trying to position herself in relation to theory is clear. She has tried to implement feedback from her lecturer but finds herself in a predicament as using her own words results in an instruction to draw on the theory and in her attempt to implement this, she is asked to insert more of her own opinions. She is mindful of the challenges faced by having to strike a balance between 'mixing with the 
books' and 'mix with your own', but has no strategies to overcome these issues. This dilemma is similarly expressed by another student:

'You can express your views but to a point, and then after that you can't anymore. So after that it becomes like your own point of view.' (Group A, S2, Male)

The boundary between his position and building on previous knowledge is unclear to him. A student in Group B also tried to articulate the quandary faced:

'That's where I find the problem, because in terms of you explaining or describe this thing in your own words, ok, fine, you go and do your readings, then you try to describe those or just to write them in your own words, then they tell you that these are not your ideas, you are taking other famous ideas. So you get confused now. They say write these in your own words and then you take these things that you read... you write them in your own words and you get a 50 ... Fine, I did the readings, and I put them in my own words, then what else should I be doing?' (Group B, S4, Male)

The power relations between students and lecturers are emphasised here and this student feels powerless. The tension he experiences is evident in his question 'what else should I be doing?' Students feel constrained in inserting their voice into their writing about theory:

'Say they tell me Vygotsky said this and that, I understand it that way, but I'm not allowed to say it in my own words. I'm supposed to say it in my own words but say the idea came from Vygotsky.' (Group C, S3, Female)

The fact that this student uses words such as 'not allowed'; ' $I$ 'm supposed to' indicates that her focus is on the punitive aspect of assessment and on the rules of writing. She sees the conventions of the genre as limiting and confusing. Her lack of self-efficacy in the face of restrictions is evident.

Our findings suggest that, rather paradoxically, the development of a student's voice is not a natural practice - it needs to be actively developed and explicitly modelled by the lecturers and tutors in each discipline. Understanding the purpose of assessment tasks plays an important role in terms of how voice is expressed in each assessment task. How to integrate, engage with or analyse the ideas from published sources into one's own argument has to be taught overtly. We support Thesen and Cooper's (2014:15) contention that through explicit teaching and learning processes, students' voices will be realised through their writing as they 'grapple with risky decisions about content and form' and manage the 'tilting point between the self and others where the other refers to ideas, beliefs, places, relationships, audiences and forms'. There are many common-sense understandings of what is meant by student voice in assessment. What is needed is a more nuanced engagement with students' specific challenges and this requires further research into the effects of the explicit teaching and modelling of voice in academic writing.

\section{Implications of the findings}

In light of the findings discussed above, we recommend the following:

- Lecturers should take part in professional development programmes, which offer cross-curricula interactions, as well as discipline-based teaching workshops that focus on the instruction of academic writing.

- Lecturers need opportunities to help develop pedagogical strategies to foreground critical thinking and articulation of this in their disciplines.

- Lecturers need to consider how they affirm and transform students' knowledge and practices in their disciplines. They need to help students to practise and master the discourses necessary to foster self-efficacy and to achieve success in their chosen disciplines in clear ways with the support of the institutions.

- Lecturers need to provide models and help students to practise how to position themselves and their arguments in relation to the theories they are taught in the disciplines. Subject specialists should be trained how to do this in collaboration with language specialists.

- Lecturers need to teach and model 'voice' in their disciplines overtly in particular how this is achieved in their disciplines and taking into account the demands of each assessment task.

- Lecturers should provide feedback that emphasises students' possibilities for development rather than focussing on how limited their work is.

\section{Conclusion}

Because students struggle with writing their assignments in their first year, it is important for lecturers and tutors to be aware of the specifics of what the struggles are and to work with students to overcome these. A key challenge is to enable lecturers to recognise that voice is multi-faceted and that the nature of voice is that it is not generic and manifests itself differently in different contexts. A core finding that emerged from the assessment project is that students' ability to exercise their voice in their first-year assessment tasks is closely related to their levels of achievement in their courses.

Flowing from our analysis of the focus group data, three dimensions of voice (genre, vocabulary and argument) have been apparent. Creating spaces for lecturers to think, speak, write, reflect and develop the confidence to articulate their understanding in their discipline will help them to recognise the different discourses and genres valued and enable them to create awareness and a metadiscourse for discussion of these with their students. We recognise the challenges presented in the face of dwindling university resources for student support, as well as increasing student numbers and the demands of these on lecturers providing substantive feedback to students when marking assignments.

Even so, students should be empowered to position themselves in ways that help them to develop a meta- 
awareness, which will help them to view assessment and academic writing as tools for development. If students can recognise the power they have to use the academic genre of each discipline to serve their purposes and recognise assessment as enabling rather than threatening, they can begin to find their voice.

\section{Acknowledgements}

The authors would like to thank Prof. Yael Shalem for her leadership and work on the study which provided the data for this article.

\section{Competing interests}

The authors declare that they have no financial or personal relationships that may have inappropriately influenced them in writing this article.

\section{Authors' contributions}

Both authors, T.G. and L.D., analysed the data and wrote the article collaboratively.

\section{References}

Angélil-Carter, S., 2000, Stolen language? Plagiarism in writing, Pearson Educational, London.

Ashwin, P., Boud, D., Coate, K., Hallet, F., Keane, E., Krause, K. et al., 2015, Reflective teaching in higher education, Bloomsbury, London.

Bakhtin, M.M., M.Holquist (ed.), 1981, 'Discourse in the novel', in The dialogic imagination: Four essays by M M Bakhtin, pp. 259-422, University of Austin Press, Austin, TX.

Bangeni, B. \& Kapp, R. (eds.), 2017, Negotiating learning and identity in higher education, Bloomsbury, London.

Blommaert, J., 2008, Grassroots literacy: Writing, identity and voice in Central Africa, Routledge, Abingdon, OX

Boughey, C. \& McKenna, S., 2016, 'Academic literacy and the decontextualised learner', Critical Studies in Teaching and Learning 4(2), 1-9. https://doi.org/ 10.14426/cristal.v4i2.80

Bourdieu, P., 1986, 'The forms of capital', in J.F. Richardson (ed.), Handbook of theory of research for the sociology of education, pp. 46-58, Transl. R. Nice, Greenwood, New York.

Bourdieu, P., 1990, The logic of practice, Transl. R. Nice, Polity Press, Cambridge.
Bourdieu, P., 1991, Language and symbolic power, Transl. R. Nice, Polity Press, Cambridge.

Bourdieu, P., 2004, Science of science and reflexivity, Transl. R. Nice, Polity Press, Cambridge.

Cadman, K., 2003, 'Divine discourse: Plagiarism, hybridity and epistemological racism' in LED 2003: First International Conference on Language, Education and Diversity, viewed 19 July 2018, from http://hdl.handle.net/2440/39833.

Carless, D., 2015, 'Exploring learning-oriented assessment processes', Higher Education 69(6), 963-976. https://doi.org/10.1007/s10734-014-9816-z

Cliff, A., 2015, 'The National Benchmark Test in academic literacy: How might it be used to support teaching in higher education?', Language Matters 46(1), 3-21. https://doi.org/10.1080/10228195.2015.1027505

Crème, P. \& Lea, M., 1997, Writing at university: A guide for students, Open University Press, Maidenhead.

Dixon, K., Reed, Y. \& Reid, J., 2013, 'Supporting teacher educator professional learning about assessment: Insights from the design and use of a task analysis tool in a first-year BEd programme', South African Journal of Higher Education 5 , 1099-1117.

Dweck, C., 2016, Mindset: The new psychology of success, Ballantine Books, London. Gee, J., 1990, Social linguistics and literacies, Falmer Press, London.

Gee, J., 2008, 'Learning in semiotic domains', in M. Prinsloo \& M. Baynham (eds.), Literacies, global and local, pp. 137-149, John Benjamin Publishing, Amsterdam.

Heath, S.B., 1983, Ways with words: Language, life and work in communities and classrooms, Cambridge University Press, Cambridge.

Luke, A., 2008, 'Pedagogy as gift', in J. Albright \& A. Luke (eds.), Pierre Bourdieu and literacy education, pp. 68-92, Routledge, New York.

Mann, S., 2001, 'Alternative perspectives on student experience: Alienation and engagement', Studies in Higher Education 26(1), 7-19. https://doi.org/10.1080/ 03075070020030689

Oostendorp, M., 2016, 'Giving voice: Studies in honour of Christine Anthonissen', Stellenbosch Papers in Linguistics Plus 49, i-iv. https://doi.org/10.5842/49-0-708

Pearce, T.C. \& Wood, B., 2016, 'Education for transformation: An evaluative framework to guide student voice work in schools', Critical Studies in Education. https://doi org/10.1080/17508487.2016.1219959

Ritchie, L., 2016, Fostering self-efficacy in higher education students, Palgrave, London.

Shalem, Y., Dison, L., Gennrich, T. \& Nkambule, T., 2013a, “'I don't understand everything here ... I'm scared": Discontinuities as experienced by first-year education students in their encounters with assessment', South African Journal of Higher Education 5, 1081-1098.

Shalem, Y, Dison, L. \& Reed, Y, 2013b, 'Towards successful participation in academic writing: What can we learn from assessment', South African Journal of Higher Education 5, 1071-1081.

Shalem, Y. \& Rusznyak, L., 2013, “Theory” for teacher practice: A typology of application tasks in teacher education', South African Journal of Higher Education 5, 1118-1134.

Slonimsky, L. \& Shalem, Y., 2006, 'Pedagogic responsiveness for academic depth', Journal of Education 40, 35-58.

Sperling, M., Appleman, D., Gilyard, K. \& Freedman, S., 2011, 'Voice in the context of literacy studies', Reading Research Quarterly 46(1), 70-84. https://doi.org/ 10.1598/RRQ.46.1.4

Thesen, L. \& Cooper, L., 2014, Risk in academic writing: Postgraduate students, their teachers and the making of knowledge, Multilingual Matters, Bristol. 